\title{
A study of essential oil from an invasive Piper aduncum $\mathbf{L}$.
}

\section{Kajian minyak atsiri dari tumbuhan invasif Piper aduncum L.}

\author{
I Putu Agus Hendra Wibawa ${ }^{1}$, Vienna Saraswaty ${ }^{2}$, Farid Kuswantoro ${ }^{1}$, Putri Sri Andila ${ }^{1}$, Putri Kesuma Wardhani ${ }^{1}$, \\ I Gede Tirta ${ }^{1}$, Wawan Sujarwo ${ }^{1, *}$ \\ ${ }^{1}$ Bali Botanical Gardens - LIPI, Candikuning, Baturiti, Tabanan Bali 82191 \\ ${ }^{2}$ Development Unit for Clean Technology - LIPI, Jl. Cisitu Sangkuriang Gd. 50 Bandung 40135
}

*Email: wawan.sujarwo@lipi.go.id

Submitted 26 January 2019; Accepted 20 July 2019

\section{INTISARI}

Tumbuhan invasif Piper aduncum merupakan spesies tumbuhan yang berpotensi menghasilkan minyak atsiri. Penelitian ini bertujuan untuk menentukan persentase, senyawa kimia yang terkandung, dan sifat antijamur dari minyak atsiri yang dihasilkan dari daun dan buah $P$. aduncum. Penelitian menunjukkan bahwa daun dan buah $P$. aduncum mengandung masing-masing 0,30\% dan 0,33\% minyak atsiri. Apiol adalah senyawa kimia paling melimpah yang diperoleh dalam minyak atsiri daun dan buah P. aduncum, masingmasing dengan konsentrasi $57,10 \%$ dan $66,31 \%$. Kami menyimpulkan bahwa minyak atsiri yang diperoleh dalam penelitian ini mampu menghambat pertumbuhan Aspergillus niger dan Cladosporium sp. namun tidak mampu menghambat Fusarium oxysporum dan Fusarium solani.

Kata kunci: Antijamur, apiol, analisis GC-MS, IAPs, fitokimia, penyakit tanaman

\begin{abstract}
An invasive Piper aduncum is a plant species that potentially produces essential oil. The study aims to determine the percentage, phytochemical compounds, and anti-fungal properties of essential oil produced from the leaves and fruits of Piper aduncum. The study showed that the leaves and fruits of P. aduncum contain $0.30 \%$ and $0.33 \%$ of essential oil, respectively. Apiol is the most abundant phytochemical compound obtained in essential oil of leaves and fruits of $P$. aduncum with $57.10 \%$ and $66.31 \%$, respectively. We conclude that essential oil obtained in this study is able to inhibit the growth of both Aspergillus niger and Cladosporium sp. but not for Fusarium oxysporum and Fusarium solani.
\end{abstract}

Keywords: Antifungal, apiol, GC-MS analysis, IAPs, phytochemistry, plant disease

\section{INTRODUCTION}

Piper aduncum is firstly introduced to Indonesia as an ornamental plant in 1860 , and now has been widely distributed throughout Indonesia (Hartemink, 2010; Tjitrosoedirdjo et al., 2016). The species is neotropic plant that grows to an altitude of 2,000 meters and generally in open and disturbed areas, such as secondary forest (Jan et al., 2002; Tjitrosoedirdjo et al., 2016), for example in Borneo land clearing for road construction is reported to have contributed to the spread of this species (Padmanaba and Sheil, 2014). Despite being an invasive plant, in Papua New Guinea this species is used for raw material of farming equipment, pesticides, fertilizers, construction of houses, and windbreaks (Siges et al., 2005).

Piper aduncum contains an essential oil which is reportedly able to prevent bites of the Aedes albopictus mosquito (Misni et al., 2009). In addition 
to being a mosquito repellent, the essential oil is widely used in the drug industry, as food flavor, in cosmetics and fragrances (Rizal et al., 2009). Essential oils are also known to inhibit fungal growth. Essential oil from lemons is known to inhibit the growth of Aspergillus parasiticum fungus, A. carbonarius, Cladosporium cladosporioides, Eurotium herbariorum and Penicillium chrysogenum (Dimic et al., 2014). Essential oil from Thymus vulgaris has also been known to inhibit the growth of the fungus Rhizopus oryzae (de Lira Mota et al., 2012).

Efforts to control Invasive Alien Plants (IAPs) are constrained by costs. However, some invasive plant species are considered having an economic value that can be created as part of control costs (Stafford \& Blignaut, 2017). This study aims to determine the yield, phytochemical content and potential anti-fungal properties of essential oil obtained from the leaves and fruits of an invasive
Piper aduncum. Also, this present study can hopefully provide a preliminary information to anyone who interested on the topic.

\section{METHODS}

\section{Study area}

All the processes and antifungal testing of essential oil of $P$. aduncum were conducted at Laboratory of Applied Botany of Bali Botanical Garden, while sequencing of phytochemical was carried out at the Development Unit for Clean Technology - LIPI. The sample materials were the leaves and fruits of $P$. Aduncum obtained from Bali Botanical Gardens with registered number XV.B.229 (Figure 1). We selected leaves which are not too young and not too old, while the fruits were mature (but not ripen yet). We considered picking period for sample materials to yield an optimum amount of essential oil.
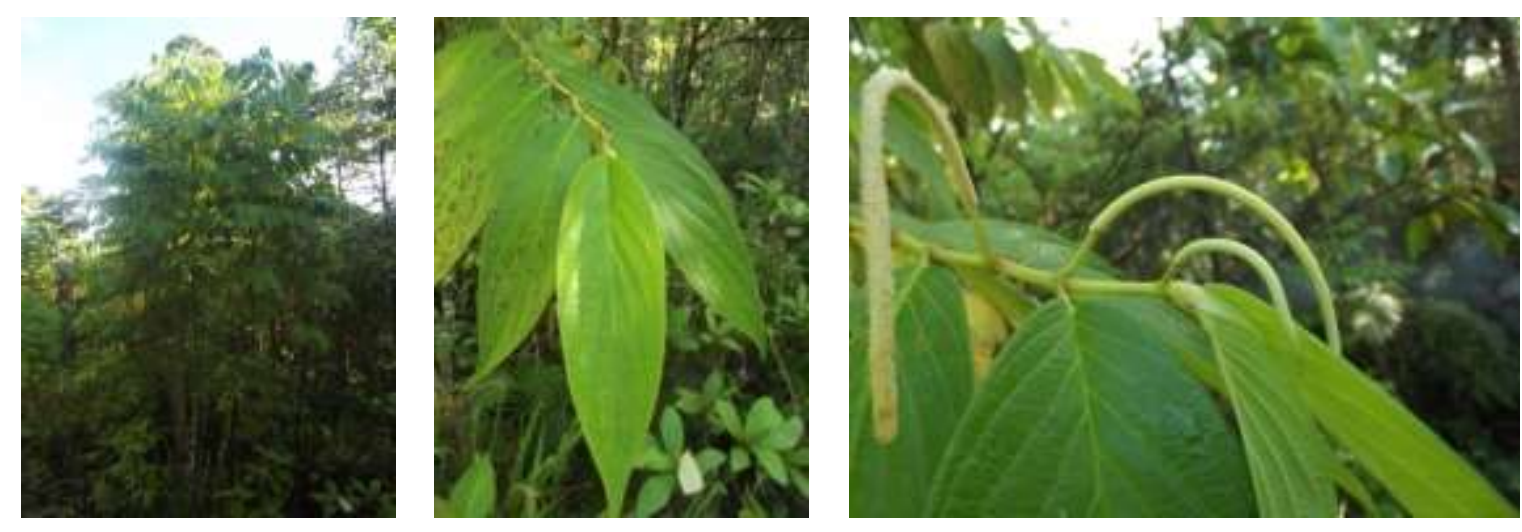

Figure 1. Piper aduncum (leaves and fruits)

\section{Extraction of Essential Oil}

A hundred grams of fresh leaves and fruits of $P$. aduncum were distilled using Schott Duran steam distiller. Heating was about five hours at temperature of $100^{\circ} \mathrm{C}$. The samples were three times replication to reduce the data errors. The essential oil was separated with the water using Schott Duran separator funnel (Handa, 2008). The separated oil was then analysed using GC-MS. The percentage of essential oil was calculated using the following formula:

$$
\text { Essential oil content }(\%)=\frac{\text { Volume of distilled oil }(\mathrm{ml})}{\text { Mass of material that was distilled }(\mathrm{gr})} X 100
$$




\section{Analysis of Chemical Components}

The essential oil samples were then analysed using Shimadzu GC-MS QP 2010. About $1 \mu \mathrm{L}$ of the sample was injected into Rtx-5MS column $(60 \mathrm{mx} 0.25 \mathrm{~mm})$ with a film thickness of $0.25 \mu \mathrm{m}$, the pre-programmed oven temperature was $50-280^{\circ} \mathrm{C}$ with a temperature rise rate of $5^{\circ} \mathrm{C} /$ minute. The carrier gas used was helium with a pressure of $101 \mathrm{kPa}$, a total flow rate of $46.5 \mathrm{~mL} /$ minute, a column flow rate of $0.85 \mathrm{~mL} /$ minute, cleaning flow rate of $3.0 \mathrm{~mL} / \mathrm{minute}$, and a split ratio of 1:50.

\section{Antifungal Assay}

The essential oil samples were tested for antifungal properties against several species of fungi, such as Aspergillus niger, Cladosporium sp. Fusarium solani and $F$. oxysporum using agar diffusion method. The method was carried out by laying moistened filter paper with essential oil on the media that had been planted with the fungus with three replications. Clear area formation was observed for three days. The formation of clear area on the surface indicated the presence of fungal death (Pratiwi, 2008).

\section{RESULTS}

\section{Extraction of Essential Oil}

The distillation of 100 gr of $P$. aduncum fruits produced $0.33 \mathrm{ml}$ of essential oil, which is equivalent to $0.33 \%$ of the gross weight of the fruits, while $100 \mathrm{gr}$ of $P$. aduncum leaves produced an average of $0.30 \mathrm{ml}$ of essential oil or $0.30 \%$ of the gross weight of the leaves (Table 1).

Table 1. Essential oil content of leaves and fruits of Piper aduncum

\begin{tabular}{llcccc}
\hline \multirow{2}{*}{ No. } & \multirow{2}{*}{ Samples } & \multicolumn{3}{c}{ Percentage of essential oil (\% v/w) } & \multirow{2}{*}{ Average } \\
\cline { 3 - 5 } & & Replication I & Replication II & Replication III & \\
\hline 1 & Leaves & 0.329 & 0.277 & 0.315 & 0.307 \\
\hline 2 & Fruit & 0.375 & 0.350 & 0.280 & 0.335 \\
\hline
\end{tabular}

\section{GC-MS analysis}

GC-MS analysis of fruits of P. aduncum showed that the Apiol was the most dominant compound $(66.31 \%)$, followed by 3-Cyclohexene-1-one, 2isopropyl-5-methyl, and Myristicin (8.21\% and
$4.38 \%$ respectively). Apiol was also the highest concentration compound found in the essential oil of $P$. aduncum leaves $(57.10 \%)$. Other compounds found in quite high concentrations of $P$. aduncum were beta-Cubebene $(6.45 \%)$, beta-Ocimene $(6.30 \%)$, and caryophyllene $(4.74 \%)$ (Table 2$)$.

Table 2. Comparison of GC-MS analysis of essential oil produced from the fruits and leaves of P. aduncum

\begin{tabular}{|c|c|c|c|c|}
\hline \multirow{2}{*}{ No } & \multirow{2}{*}{ Name of Compound } & \multirow{2}{*}{ Ret. Time } & Fruits & Leaves \\
\hline & & & $(\%)$ & $(\%)$ \\
\hline 1 & $\begin{array}{l}\text { Bicyclo[3.1.0]hex-2-ene, 2-methyl-5-(1-methylethyl)- or 3-Thujene or } \\
\text { alpha.-Thujene or Origanene or 5-Isopropyl-2-methylbicyclo[3.1.0]hex-2- } \\
\text { ene \# or 2-Methyl-5-(1-methylethyl)-bicyclo(3.1.0)hex-2-ene \$ }\end{array}$ & 7.635 & 0.58 & - \\
\hline 2 & $\begin{array}{l}\text { (1R)-2,6,6-Trimethylbicyclo[3.1.1]hept-2-ene or 1R-.alpha.-Pinene or } \\
\text { Bicyclo[3.1.1]hept-2-ene, 2,6,6-trimethyl-, } \quad(1 \mathrm{R}) \text { - or } 2,6,6- \\
\text { Trimethylbicyclo[3.1.1]hept-2-ene-, (1R,5R)- or d-.alpha.-Pinene or 1R- } \\
\text { (+)-.alpha.-Pinene or (R)-.alpha.-Pinene }\end{array}$ & $7.856-7.859$ & 1.08 & 0.66 \\
\hline 3 & $\begin{array}{l}\text { Bicyclo[3.1.1]heptane, 6,6-dimethyl-2-methylene-, (1S)- or 2(10)-Pinene, } \\
\text { (1S,5S)-(-)- or (-)-.beta.-Pinene or (-)-2(10)-Pinene or L-.beta.-Pinene or } \\
\text { (1S)-(-)-.beta.-Pinene or laevo-.beta.-Pinene or 6,6-Dimethyl-2- } \\
\text { methylenebicyclo[3.1.1]heptane-, } \quad \text { (S)- or (-)-beta-Pinene or } \\
\text { Bicyclo(3.1.1)heptane, 6,6-dimethyl-2-methylene-, (1S,5S)- or (-)-Pin- } \\
\text { 2(10)-ene }\end{array}$ & $9.356-9.357$ & 1.08 & 0.55 \\
\hline
\end{tabular}


Table 2. (cont) Comparison of GC-MS analysis of essential oil produced from the fruits and leaves of $P$. aduncum

\begin{tabular}{|c|c|c|c|c|}
\hline \multirow[b]{2}{*}{ No } & \multirow{2}{*}{ Name of Compound } & \multirow{2}{*}{ Ret. Time } & \multirow{2}{*}{$\begin{array}{c}\text { Fruits } \\
(\%)\end{array}$} & \multirow{2}{*}{$\frac{\text { Leaves }}{(\%)}$} \\
\hline & & & & \\
\hline 4 & $\begin{array}{l}\text { alpha.-Phellandrene or 1,3-Cyclohexadiene, 2-methyl-5-(1-methylethyl)- } \\
\text { or .alpha.-Fellandrene or p-Mentha-1,5-diene or 5-Isopropyl-2-methyl-1,3- } \\
\text { cyclohexadiene or 2-methyl-5-(1-methylethyl)-1,3-cyclohexadiene or 4- } \\
\text { Isopropyl-1-methyl-1,5-cyclohexadiene or 2-Methyl-5-isopropyl-1,3- } \\
\text { cyclohexadiene or alpha-Phellandrene or 5-Isopropyl-2-methyl-cyclohexa- } \\
\text { 1,3-diene or Menthadiene }\end{array}$ & $10.377-10.380$ & 1.27 & 0.67 \\
\hline
\end{tabular}

5 1,3-Cyclohexadiene, 1-methyl-4-(1-methylethyl)- or .alpha.-Terpinene or .alpha.-Terpinen or p-Mentha-1,3-diene or Terpilene or 1-Isopropyl-4methyl-1,3-cyclohexadiene or 1-methyl-4-(1-methylethyl)-1,3cyclohexadiene or 1,3-Cyclohexadiene, 1-methyl-4-isopropyl- or 1Methyl-4-isopropylcyclohexadiene-1,3 or .alpha.-Terpine or 1-Methyl-4isopropyl-1,3-cyclohexadiene or alpha-Terpineneor 1-Isopropyl-4-methylcyclohexa-1,3-diene

\begin{tabular}{|c|c|c|c|c|}
\hline 6 & $\begin{array}{l}\text {.alpha.-Pinene or Bicyclo[3.1.1]hept-2-ene, 2,6,6-trimethyl- or 2-Pinene or } \\
\text { 2,6,6-Trimethylbicyclo[3.1.1]hept-2-ene or Pinene, .alpha. }\end{array}$ & 11.684 & - & 2.85 \\
\hline 7 & 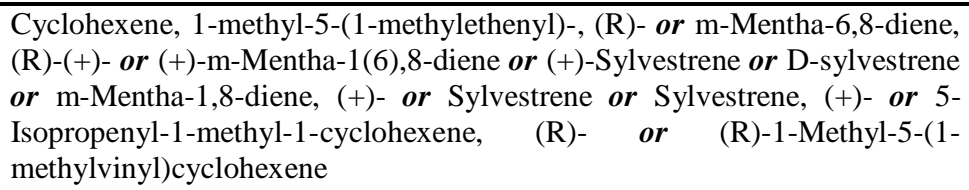 & $11.290-11.291$ & 2.90 & 1.99 \\
\hline 8 & $\begin{array}{l}\text {.beta.-Ocimene or 1,3,6-Octatriene, 3,7-dimethyl- or Ocimene or 3,7- } \\
\text { Dimethyl-1,3,6-octatriene or beta-Ocimene }\end{array}$ & $12.038-12.093$ & 0.79 & 6.30 \\
\hline 9 & $\begin{array}{l}\text { gamma.-Terpinene or 1,4-Cyclohexadiene, 1-methyl-4-(1-methylethyl)- or } \\
\text {.gamma-Terpinen or p-Mentha-1,4-diene or Crithmene or Moslene or 1- } \\
\text { methyl-4-(1-methylethyl)-1,4-cyclohexadiene or 1-Methyl-4-isopropyl-1,4- } \\
\text { cyclohexadiene or 1-Methyl-4-isopropylcyclohexadiene-1,4 or 1,4-p- } \\
\text { Menthadiene or 1,4-Cyclohexadiene, 1-methyl-4-isopropyl- or 4- } \\
\text { Isopropyl-1-methyl-1,4-cyclohexadiene or gamma-Terpinene or 1- } \\
\text { Isopropyl-4-methyl-1,4-cyclohexadiene \# or 1-Isopropyl-4-methyl- } \\
\text { cyclohexa-1,4-diene }\end{array}$ & $12.417-12.429$ & 1.98 & 1.55 \\
\hline 10 & $\begin{array}{l}\text { 2-Carene or Bicyclo[4.1.0]hept-2-ene, 3,7,7-trimethyl- or .delta.-2-Carene } \\
\text { or (.+/-.)-2-Carene or 3,7,7-Trimethylbicyclo[4.1.0]hept-2-ene }\end{array}$ & 13.502 & 0.63 & - \\
\hline 11 & $\begin{array}{l}\text { 1,6-Octadien-3-ol, 3,7-dimethyl- or .beta.-Linalool or Linalol or Linalool } \\
\text { or Linalyl alcohol or 2,6-Dimethyl-2,7-octadien-6-ol or allo-Ocimenol or } \\
2,6-D i m e t h y l-2,7-o c t a d i e n e-6-o l \text { or 2,6-Dimethylocta-2,7-dien-6-ol or 3,7- } \\
\text { Dimethyl-1,6-octadien-3-ol or 3,7-Dimethylocta-1,6-dien-3-ol or Linolool } \\
\text { or Linanool or 3,7-Dimethyl-octa-1,6-dien-3-ol or dl-3,7-Dimethyl-3- } \\
\text { hydroxy-1,6-octadiene or Linalool ex bois de rose oil or Linalool ex ho oil } \\
\text { or Linalool ex orange oil or Phantol or Linalool, beta. }\end{array}$ & 13.977 & 0.63 & - \\
\hline 12 & $\begin{array}{l}\text { 3-Cyclohexen-1-ol, 4-methyl-1-(1-methylethyl)-, (R)- or p-Menth-1-en-4- } \\
\text { ol, (R)-(-)- or (-)-Terpinen-4-ol or (-)-4-Terpineol or L-terpinen-4-ol or L- } \\
\text { 4-terpineneol or L-4-terpineol }\end{array}$ & $16.826-16.819$ & 1.90 & 0.57 \\
\hline 13 & $\begin{array}{l}\text { 3-Cyclohexen-1-one, 2-isopropyl-5-methyl- or 2-Isopropyl-5-methyl-3- } \\
\text { cyclohexen-1-one }\end{array}$ & $19.615-19.668$ & 8.21 & 2.89 \\
\hline 14 & .alfa.-Copaene & $23.686-23.692$ & 0.60 & 0.55 \\
\hline 15 & $\begin{array}{l}\text { Caryophyllene or Bicyclo[7.2.0]undec-4-ene, 4,11,11-trimethyl-8- } \\
\text { methylene-, [1R-(1R*,4E,9S*)]- or Bicyclo[7.2.0]undec-4-ene, 4,11,11- } \\
\text { trimethyl-8-methylene-, (E)-(1R,9S)-(-)- or .beta.-Caryophyllen or .beta.- } \\
\text { Caryophyllene or trans-Caryophyllene or L-Caryophyllene or } \\
\text { Bicyclo(7.2.0)undec-4-ene, 8-methylene-4,11,11-trimethyl-, (E)-(1R,9S)-(- } \\
\text { )- or 8-Methylene-4,11,11-(trimethyl)bicyclo(7.2.0)undec-4-ene, } \\
\text { (1R,4E,9S)- or beta-Caryophyllene or .beta.-(E)-Caryophyllene or .beta.- } \\
\text { trans-Caryophyllene or Caryophyllen }\end{array}$ & $25.128-25.157$ & 2.24 & 4.74 \\
\hline 16 & $\begin{array}{lcccc}\text { 1,4,7,-Cycloundecatriene, } & 1,5,9,9 \text {-tetramethyl-, } & \text { Z,Z,Z- } & \text { or } & 1,5,9,9- \\
\text { Tetramethyl-1,4,7-cycloundecatriene }\end{array}$ & $26.209-26.226$ & 1.39 & 2.35 \\
\hline 17 & beta.-copaene & 27.075 & 1.40 & \\
\hline
\end{tabular}


Table 2. (cont) Comparison of GC-MS analysis of essential oil produced from the fruits and leaves of $P$. aduncum

\begin{tabular}{|c|c|c|c|c|}
\hline \multirow[b]{2}{*}{ No } & \multirow{2}{*}{ Name of Compound } & \multirow{2}{*}{ Ret. Time } & \multirow{2}{*}{$\frac{\text { Fruits }}{(\%)}$} & \multirow{2}{*}{$\frac{\text { Leaves }}{(\%)}$} \\
\hline & & & & \\
\hline 18 & $\begin{array}{l}\text { 1H-Cyclopenta[1,3]cyclopropa[1,2]benzene, } \\
\text { methylene-4-(1-methylethyl)-, }\end{array}$ & 27.125 & - & 6.45 \\
\hline 19 & $\begin{array}{l}\text { Cyclohexane, 1-ethenyl-1-methyl-2-(1-methylethenyl)-4-(1- } \\
\text { methylethylidene)- or o-Menth-8-ene, 4-isopropylidene-1-vinyl- or Elixene } \\
\text { or 2-Isopropenyl-1-methyl-4-(1-methylethylidene)-1-vinylcyclohexane }\end{array}$ & 27.584 & - & 2.73 \\
\hline 20 & $\begin{array}{l}\text { alpha.-Farnesene or 1,3,6,10-Dodecatetraene, 3,7,11-trimethyl-, (E,E)- or } \\
\text { Farnesene or 2,6,10-Trimethyl-2,6,9,11-dodecatetraene, trans- or 3,7,11- } \\
\text { Trimethyl-1,3,6,10-dodecatetraene, (trans,trans)- }\end{array}$ & 27.867 & - & 1.84 \\
\hline 21 & Cubedol & $28.148-28.168$ & 0.55 & 1.11 \\
\hline 22 & $\begin{array}{l}\text { 1,3-Benzodioxole, 4-methoxy-6-(2-propenyl)- or Benzene, 5-allyl-1- } \\
\text { methoxy-2,3-(methylenedioxy)- or Myristicin or 5-Allyl-1-methoxy-2,3- } \\
\text { (methylenedioxy)benzene or 6-Allyl-4-methoxy-1,3-benzodioxole or } \\
\text { Myristicine }\end{array}$ & $28.366-28.394$ & 4.38 & 1.64 \\
\hline 23 & $\begin{array}{l}\text { 1,5-Cyclodecadiene, 1,5-dimethyl-8-(1-methylethylidene)-, }(\mathrm{E}, \mathrm{E})-\text { or } \\
\text { Germacrene B or Germacra-1(10),4,7(11)-triene or Germacra- } \\
\text { 1(10),4,7(11)-triene, (E,E)- or 1,5-Dimethyl-8-(1-methylethylidene)-1,5- } \\
\text { cyclodecadiene }\end{array}$ & 29.435 & - & 0.90 \\
\hline 24 & Viridiflorol & 30.573 & - & 2.56 \\
\hline 25 & $\begin{array}{l}\text { Apiol or 1,3-Benzodioxole, 4,7-dimethoxy-5-(2-propenyl)- or Benzene, 1- } \\
\text { allyl-2,5-dimethoxy-3,4-(methylenedioxy)- or Apiole or Apioline or } \\
\text { Parsley apiole or Parsley camphor or 1-Allyl-2,5-dimethoxy-3,4- } \\
\text { (methylenedioxy)benzene or 4,7-Dimethoxy-5-(2-propenyl)-1,3- } \\
\text { benzodioxole or 5-Allyl-4,7-dimethoxy-1,3-benzodioxole \# or 1,3- } \\
\text { Benzodioxole, 4,7-dimethoxy-5-(2-propen-1-yl)- }\end{array}$ & $32.020-32.064$ & 66.31 & 57.10 \\
\hline 26 & $\begin{array}{l}\text { Benzene, 1,2,3-trimethoxy-5-(2-propenyl)- or Benzene, 5-allyl-1,2,3- } \\
\text { trimethoxy- or Elemicin or 3,4,5-Trimethoxyallylbenzene or 5-Allyl-1,2,3- } \\
\text { trimethoxybenzene or 1,2,3-Trimethoxy-5-(2-propenyl)-benzene or 1,2,3- } \\
\text { Trimethoxy-5-allylbenzene or 4-Allyl-1,2,6-trimethoxybenzene or } \\
\text { Benzene, 5-(2-propenyl)-1,2,3-trimethoxy or Elemicine }\end{array}$ & 32.347 & 1.05 & - \\
\hline
\end{tabular}

\section{Antifungal assay}

Inhibition test on fungi showed an inhibition zone on the inoculated medium of Aspergillus niger and Cladosporium sp., but not on the inoculated medium of Fusarium oxysporum and F. Solani (Table 3). The formation of inhibition zones (Figure 2 ) on the inoculated medium of $A$. niger and Cladosporium sp. showed that essential oil of $P$. aduncum inhibits the fungus growth.

Table 3. Response of $P$. aduncum essential oil on antifungal assay

\begin{tabular}{lcccc}
\hline & \multicolumn{4}{c}{ Anti-fungal activity towards } \\
\cline { 2 - 5 } & A. niger & Cladosporium sp. & F. oxysporum & F. solani \\
\hline$P$. aduncum Fruit & + & + & - & - \\
\hline$P$. aduncum Leaves & + & + & - & - \\
\hline
\end{tabular}




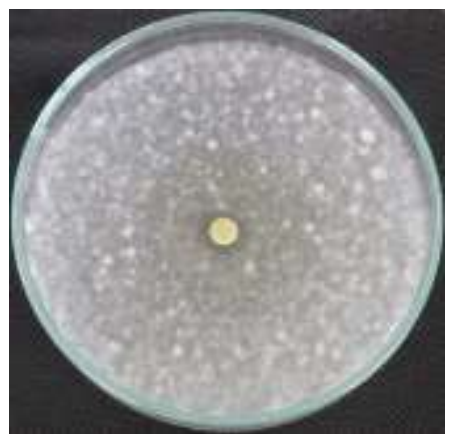

(a)

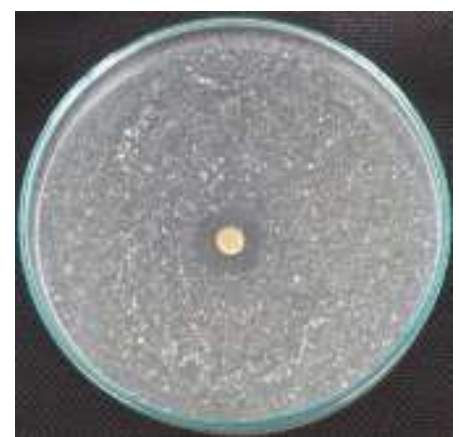

(b)

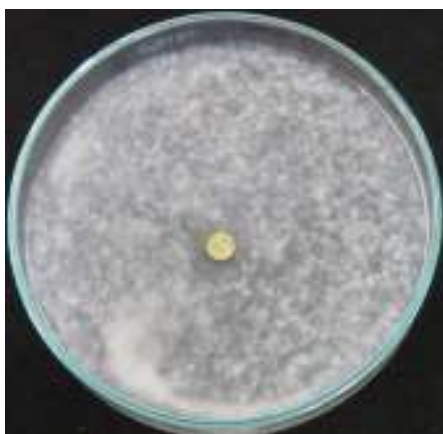

(c)

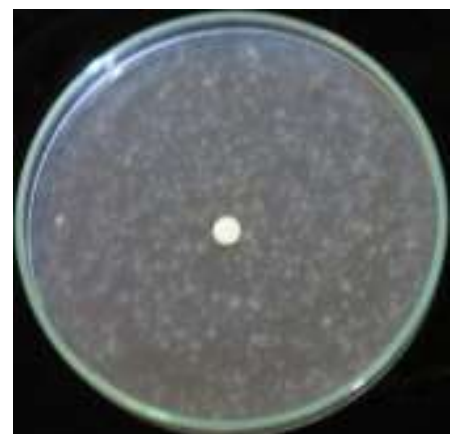

(d)

Figure 2. Observation results of antifungal assay (a) A. niger; (b) Cladosporium sp.; (c) F. Oxysporum; and (d) F. solani

\section{DISCUSSION}

Apiol and Myristicin found in the essential oil of $P$. aduncum fruits and leaves are toxic to insects (Lichtenstein \& Casida, 1963; Lichtenstein et al., 1974; Fuhremann and Lichtenstein, 1979; Bernard et al., 1995; Walia et al., 2004), thus the presence of these compounds in high concentrations promotes an opportunity to use $P$. aduncum essential oil as a natural insect repellent. In addition to Apiol, in a large percentage, the essential oil of $P$. aduncum leaves also contains caryophyllene. This compound is often found in essential oils of various species of Piperaceae family member, including $P$. cernuum and $P$. regnellii (Costantin et al., 2001; da Silva et al., 2017).

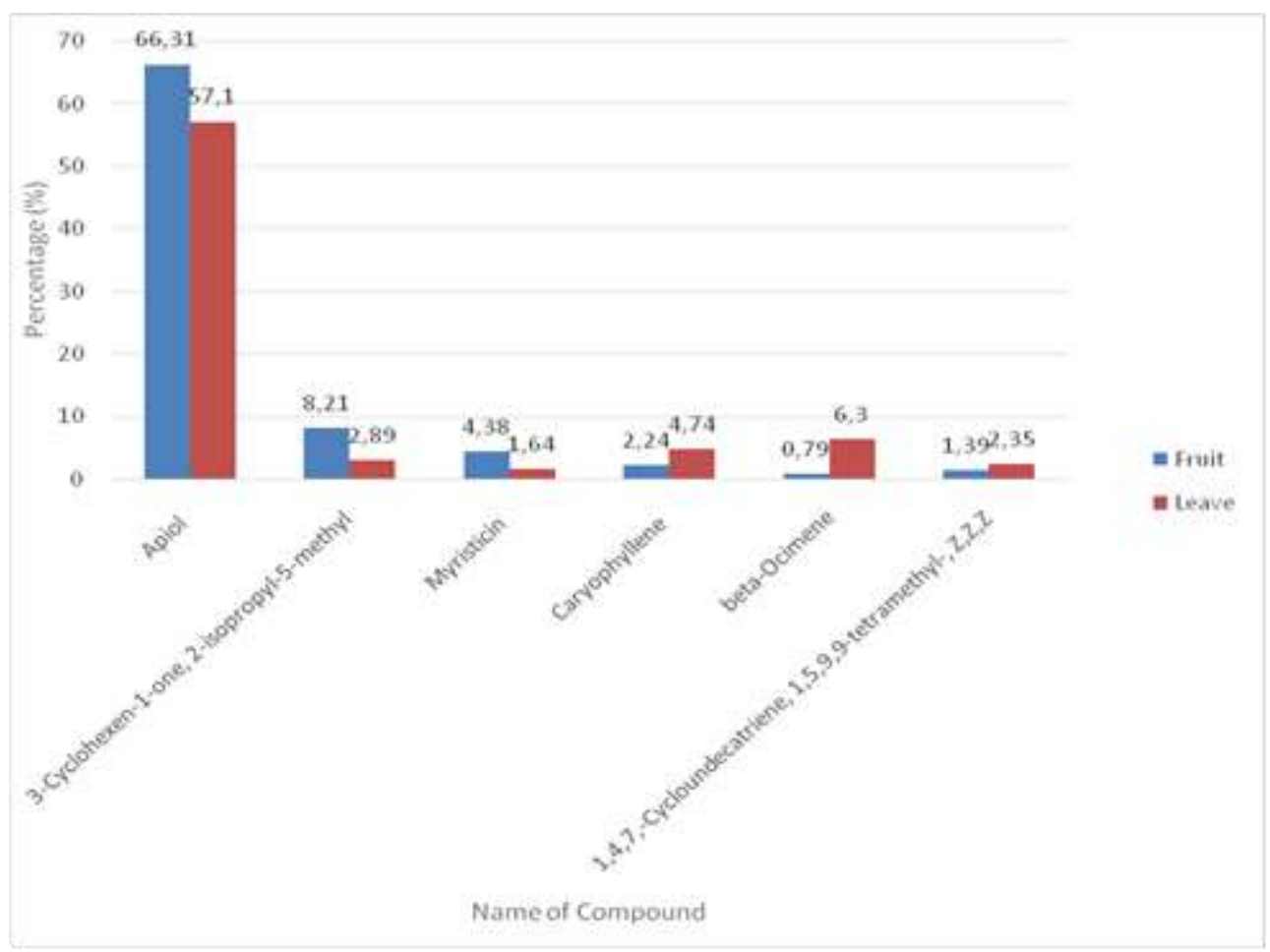

Figure 3. Comparison of some dominant chemical compounds in essential oils, obtained in fruits and leaves of $P$. aduncum.

Some dominant compounds obtained in the fruits are also found in the leaves with different concentrations. The ratio of such compounds can be seen in Figure 3. This present study showed that the leaves and fruits of $P$. aduncum are both dominated by terpenoids, these compounds are known having many biological activities, such as antimicrobial, antifungal and antibacterial (Cavaleiro, 2015). 
The inhibitory ability is likely to correlate with the presence of beta-Ocimene compounds. Cavaleiro et al. (2015) reported beta-Ocimene is a compound with antifungal properties. The compund is also reported having anti-inflammatory and antiviral properties (Terpene, 2018). On the contrary, ineffectiveness in inhibiting the growth of $F$. oxysporum and $F$. solani was probably because the nature of active ingredients has no wide spectrum, it means the essential oil only inhibits the growth of some fungus species (Neu and Gootz, 2001).

Previous studies of $P$. aduncum extraction showed various yields of essential oil. For example, leaves and branches samples of $P$. aduncum from eight different regions of the Amazon produce essential oil ranging from $1.2 \%$ to $3.3 \%$ (Maia et al., 1998). Piper aduncum leaves, native to Papua New Guinea, yields essential oil of $0.35 \%$, while $P$. aduncum leaves from Cuba yields essential oil of 0.96\% (Pino et al., 2004; Rali et al., 2007). The difference in yields of essential oil is probably due to different soil macronutrients in each region. Kahkashan et al. (2015) stated that soil types affected the amount of essential oil produced by Mentha arvensis L. Suryawati \& Murniyanto (2011) showed that essential oil produced by Zingiber officinale L. is directly proportional to the availability of macronutrients in the soil. A lack of available groundwater can also result in changing secondary metabolites of plants than in normal conditions (Trisilawati \& Pitono, 2012).

\section{CONCLUSION}

The present study concluded that essential oil of the leaves and fruits of $P$. aduncum contained Apiol compounds in high concentrations. The essential oil has been confirmed to inhibit the growth of Aspergillus niger and Cladosporium sp. The study promoted possibilities that essential oil of $P$. aduncum could be developed into industrial production of fungicides and insecticides. However, natural products should respect to cultivation, collection, and used in sustainable manner which conserves both of the plants materials and the environment.

\section{ACKNOWLEDGMENTS}

This study is financially supported by Bali Botanical Gardens. The authors would like to thank to I Gede Tirta and all colleagues who helped in the research and providing technical assistances.

\section{REFERENCES}

Bernard, C.B., H.G. Krishinamurty, D. Chauret, T. Durst, B.J.R. Philogene, P. Sanches-Vindas, C. Hasbaun, I. Poveda, L.S.Roman, J.T. Arnason. 1995. Insecticidal defenses of Piperaceae from the neotropics. J. Chem. Ecol. 21: 801-814.

Cavaleiro, C., L. Salgueiro, M. Gonçalves, K. Hrimpeng, J. Pinto, E. Pinto. 2015. Antifungal activity of the essential oil of Angelica major against Candida, Cryptococcus, Aspergillus and dermatophyte species. Journal of Natural Medicines 69(2): 241-248.

Costantin, M.B., P.Sartorelli, R. Limberger, A.T. Henriques, M. Steppe, M.J.P. Ferreira, M.T. Ohara, V.P. Emerenciano and M.J. Kato. 2001. Essential oils from Piper cernuum and Piper regnellii: Antimicrobial activities and analysis by GC/MS and ${ }^{13} \mathrm{C}-\mathrm{NMR}$. Planta Med. 67(8): 771-773. doi:10.1055/s-2001-18363

da Silva, J.K., R. da Trindade, N.S. Alves, P.L. Figueiredo, JGS. Maia and W.N. Setzer. 2017. Essential oils from neotropical Piper species and their biological activities. Int. J. Mol. Sci. 18: 2571. doi:10.3390/ijms18122571

de Lira Mota, K.S., F. de Oliveira Pereira, W.A. de Oliveira, I.O. Lima and E de Oliveira Lima. 2012. Antifungal activity of Thymus vulgaris L. essential oil and its constituent phytochemicals against Rhizopus oryzae: interaction with ergosterol. Molecules 17:14418-14433. doi:10.3390/molecules 171214418

Dimic,G., S.Kocic-Tanackov, L.Mojovic and J. Pejin. 2014. Antifungal activity of Lemon essential oil, coriander and cinnamon extracts on foodborne molds in direct contact and the vapor phase. Journal of Food Processing and Preservation 39(6):1778-1787. doi: 10.1111/jfpp.12410. 
Fuhremann, T.W. and E.P. Lichtenstein, E.P. 1979. Insecticide toxicity and degradation in houseflies as affected by naturally occurring food plant components. Journal of Agricultural and Food Chemistry 27:87-91.

Hartemink, A.E. 2010. The invasive shrub Piper aduncum in Papua New Guinea: a review. Journal of Tropical Forest Science 22(2): 202213.

Handa, S.S. 2008. An overview of extraction techniques for medicinal and aromatic plants. In: Handa, S.S., S.P.S. Khanuja, G. Longo, D.D. Rakesh (Eds.). Extraction technologies for medicinal and aromatic plants. ICS-UNIDO. Trieste, Italy. pp: 42-47.

Jan, L., V. Novovotny., L. Cizek, K. Molem., B. Isua., W. Boen, R. Kutil., J. Auga., M. Kasbal., M. Manumbor and S. Hiuk. 2002. Successful invasion of the neotropical species Piper aduncum in rain forests in Papua New Guinea. Applied Vegetation Science 5: 255-262.

Kahkashan, P., B. Najat, S. Iram and S. Iffat. 2016. Influence of soil type on the growth parameters, essential oil yield and biochemical contents of Mentha arvensis L. Journal of Essential Oil Bearing Plants 19(1): 76-81. doi: 10.1080/0972060X.2015.1086285

Lichtenstein E.P. and J.E.Casida. 1963. Myristicin, an insecticide and synergistic occuring naturally in the edible parts of parsnip. Journal of Agricultural and Food Chemistry 11: 410415.

Lichtenstein, E.P., T.T. Liang, K.R. Schulz, H.K. Schnoes, and G.T. Carter. 1974. Insecticidal and sinergistic components isolated from dill plants. Journal of Agricultural and Food Chemistry (22): 658-664.

Maia, J.G.S., M. G. B. Zohhbi., E. H. A. Andrade., A. S. Santos., M. H. L. da Silva., A. I. R. Luz and C. B. Bastos. 1998. Constituents of the essential oil of Piper aduncum L. growing wild in the Amazon region. Flavour Fragr. J. (13): 269-272.

Misni, N., S. Sulaiman., H. Othman and B. Umar. 2009. Repellency of essential oil of Piper aduncum against Aedes albopictus in the laboratory. Journal of the American Mosquito Control Association 25(4):442-447.

Neu, H.C. and T.D. Gootz. 2001. Antimicrobial chemotherapy. In: Baron, S. (Ed.). Medical Microbiology. $5^{\text {th }}($ Ed.) Galvestone. The University of Texas Medical Branch.

Padmanaba, M. and D. Sheil. 2014. Spread of the invasive alien species Piper aduncum via logging roads in Borneo. Tropical Conservation Science 7 (1):35-44.

Pino, J.A., R. Marbot, A. Bello and A. Urquiola. 2004. Essential Oils of Piper peltata L. Miq. and Piper aduncum L. from Cuba. J. Essent. Oil Res. 16:124-126.

Pratiwi, S.T. 2008. Mikrobiologi Farmasi.Yogyakarta: Penerbit Erlangga. 176 hal.

Rali, T., S. W. Wossa, D. N. Leach and P. G. Waterman. 2007. Volatile chemical constituents of Piper aduncum L and Piper gibbilimbum C. DC (Piperaceae) from Papua New Guinea. Molecules 12: 389-394.

Rizal, M., M.S.Rusli, dan A. Mulyadi. 2009. Minyak Atsiri Indonesia. IPB. Bogor.

Stafford, W. and J. Blignaut. 2017.Reducing landscape restoration costs: Feasibility of generating electricity from invasive alien plant biomass on the Agulhas Plain, South Africa. Ecosystem Services 27: 224-231. doi:10.1016/j.ecoser.2017.04.008

Siges, T. H., A. E. Hartemink., P. Hebinck and J. Allen. 2005. The Invasive shrub Piper aduncum and rural livelihoods in the Finschhafen area of Papua New Guinea. Human Ecology 33(6).

Suryawati S. dan E. Murniyanto. 2011. Hubungan sifat tanah Madura dengan kandungan minyak atsiri dan tingkat kelarutannya pada jahe (Zingiber officinale L). Agrovigor 4 (2) : 99 104.

Terpene. 2018. Everything Terpenes. http://terpene.info/terpene/ocimene/. (Diakses Maret 2016).

Tjitrosoedirdjo, S.S., I. Mawardi and S. Tjitrosoedirdjo. 2016. 75 Important invasive 
alien plant species in Indonesia. SEAMEO BIOTROP Southeast Asian Regional Centre for Tropical Biology. p. 55.

Trisilawati O. dan J. Pitono. 2012. Pengaruh cekaman defisit air terhadap pembentukan bahan aktif pada purwoceng. Bul Littro. 23(1):34-47.

Walia, S., S. Saha, B.S. Parmar. 2004. Liquid chromatographic method for the analysis of two plant based insecticide synergist dillapiole and dihydrodillapiole. J. Chromatogr. 1047(2): 229-233. 